\title{
Evaluating Indian Professionals Knowledge for Innovation and Need for Patent Education
}

\author{
Sonu Gupta, Ravinder Nath Bansal, Surender Pal Singh Sodhi, \\ Gursimrat Kaur Brar \\ Baba Farid University of Health Sciences, Faridkot, India \\ sonu.dr@gmail.com
}

\section{ARTICLE HISTORY \\ Received : 2021-05-29 \\ Revised : 2021-07-10 \\ Accepted : 2021-07-26}

\section{KEYWORDS}

\section{Patent}

Invention

Indian Patent System

Medical Methods

Patent Education

Health Care Professionals

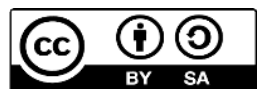

\begin{abstract}
The Patent system encourages invention, disclosure, and investment. Several patents are granted in medical sciences, but a misconception remains with health care professionals regarding criteria for patentability of their valuable invention. Though the Indian Patent system has promoted the progress of science and technology, its scope has not been extended to treatment procedures in medical and dental sciences. This research was conducted to assess the knowledge and awareness of health care professionals about the Indian patent system. The study was conducted to assess the awareness and knowledge of the Indian patent system and the need for patent education among professionals of different streams. This cross-sectional study was carried out among private practitioners of different streams (medical and dental, ayurvedic, and homeopathic). Results made a poor show of patent education and knowledge. Only $6 \%$ of participants had more than $50 \%$ knowledge regarding this topic. Since educational institutions are opting for accreditations. Research and innovation is an important criterion for that. This study highlighted that there is a great need for patent education for professional and institutional growth.
\end{abstract}

\section{Introduction}

Intellectual property (IP) has a remarkable role in the current economy. Intellectual labor along with innovation may benefit at the public level if given due significance. IP is a novel concept generated in the human mind or intellect, artistic, technical, scientific, or literary. Intellectual property right (IPR) is a legal right or exclusive right granted to the creator or inventor so that he/she can protect his/her invention for a definite period of time. IPR protects funds, investments, time spent in the invention, and cost utilized in addition to efforts. Similar to other properties, IPR can also be transferred or sold. (Saha \& Bhattacharya, 2011) The patent is an intellectual property right. Its protection ensures a fair return for companies on their investment or the cost of making a product from an invention.

Patent rights are obtained by filing a patent application in the patent office. (Heus et al., 2017) Graduates, students in educational institutes, and universities are indulged in innovation. Hence projects and innovative work needs support which in turn adds to reputation (Kassiri, Corejova, 2015). The Patent system encourages progression in science \& technology. It provides incentives for an invention, disclosure, and investment, which encourages innovation and efficient use of that invention. Developing countries are taking remarkable inspiration from developed countries to efficiently use the patent system to improve the economy which is the most important aspect. In the era of evidence based medicine health care professionals are incorporating rigorous efforts for research and development. Medical methods are excluded from the scope of patentable subject matter in most of the countries on the grounds of ethical issues in medicine. (WMA Statement on Patenting Medical Procedures, 2019) Medical devices range from simple products i.e. disposable gloves to highly technical and complex products i.e. surgical implants. Diagnostic kits and drug delivery systems are also included in this category.

Devices are required to yield results equivalent to clinical trials of medicinal products to prove their safety and efficacy. Section 4A of the Patents Act 1977 (as amended by the Patents Act 2004) states that methods for treatment of the human body or animals by surgery or therapy and diagnostic methods are not patentable whereas patents for medical devices are possible (Intellectual property and access to medicines, 2012). Patent protection can be granted for surgical, diagnostic or therapeutic instruments or apparatus if they demonstrate novelty with regard to 
the way to be used in surgery or therapy. Patent protection for a known medical device (e.g. an injector pen for injecting insulin) cannot be provided for supplementary use (same injector pen to deliver another drug for the treatment of a different illness). A few products fall on the margin between medical devices and medicinal products. (Fact SheetIntellectual property considerations for medical devices, 2018). IPR management of medical devices, treatment, and diagnostics is very important (Dixit et al., 2011). According to Section 4A, If medical methods are patented, they should have an industrial application, but they do not have any such effect (WMA Statement On Patenting Medical Procedures, 2019., Indian patent act 1970, 2015). If the Indian patent system permits patent of these methods, then it can serve several advantages, as shown in fig.1 (Gupta et al., 2018; Method of Treatment A Patent Perspective, 2017, Kassiri, Corejova, 2015).

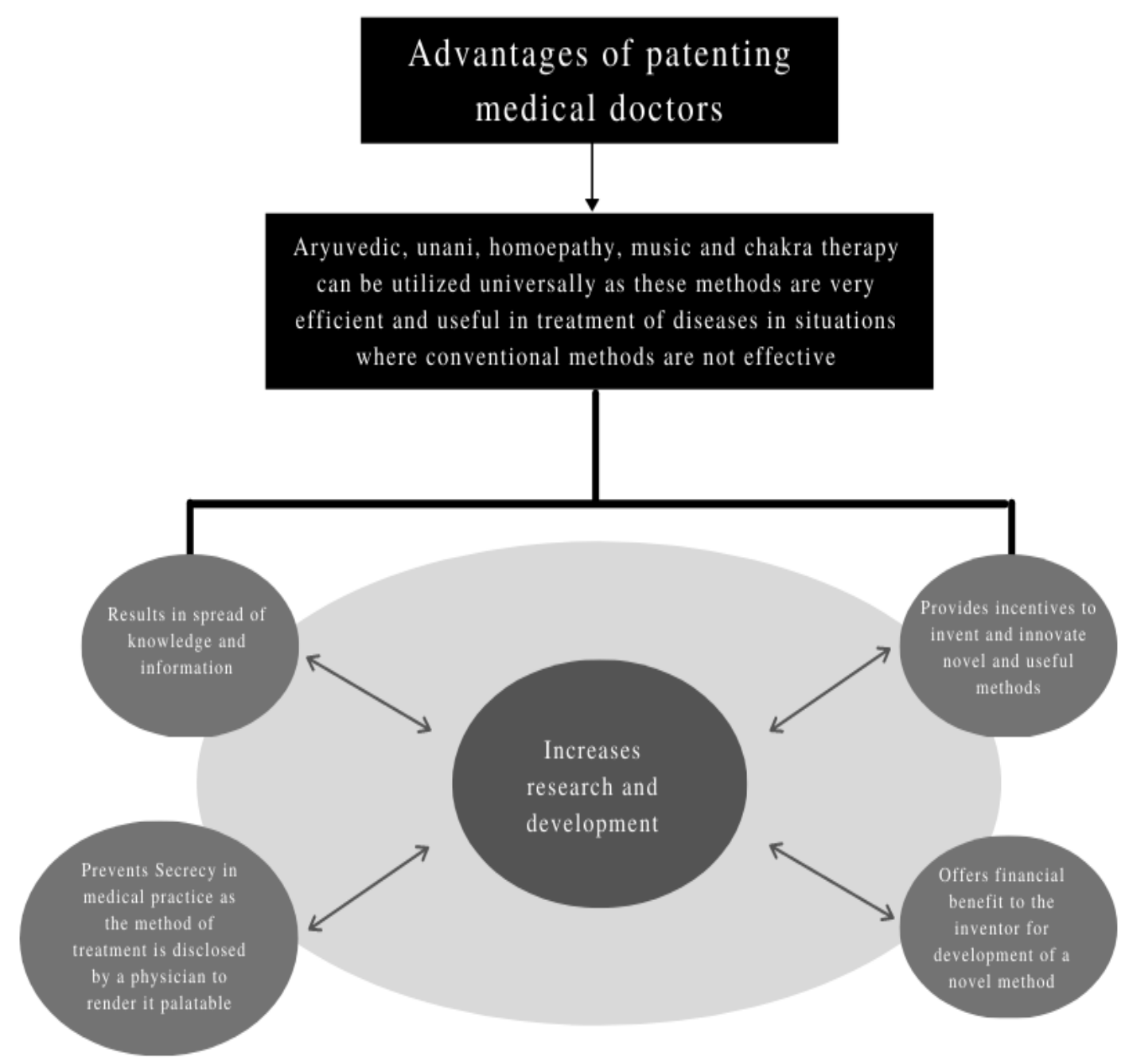

Figure 1. Advantages of Patenting Medical Methods

As per Section 3(i), any process carried out for the prophylactic, curative, surgical, medicinal, or any other therapy for humans/animals/ plants to cure a disease or money-making is non-patentable. (Indian patent act 1970, 2015). Examples of some methods are shown in table 1 and table 2.

Table 1. Method for treatment by surgery or therapy or medicinally and diagnostic and therapeutic method excluded from patentability (Examination Guidelines for Patent Applications relating to Medical Inventions in the Intellectual Property Office (2016) 


\begin{tabular}{ll}
\hline Method for Treatment & \multicolumn{1}{c}{ Example } \\
\hline Surgery & $\begin{array}{l}\text { surgical treatment including incision, excision, injection and implant insertion, } \\
\text { maintenance, operation, and extraction of a medical device like a catheter, } \\
\text { endoscope inside the human body } \\
\text { preparatory treatment for surgery- anesthesia for surgery and disinfection of skin } \\
\text { before injection/incision } \\
\text { cosmetic methods }\end{array}$ \\
\hline providing medicine or physical treatment to a patient - \\
for disease cure or control \\
implanting of a medical device or transplant of an organ - \\
preventing a disease -e.g., tooth decay or influenza \\
maintenance of physical health -.e.g. massage or Yoga or Pranayama
\end{tabular}

Table 2. Few Examples of Patent Applications in Medical and Dental Sciences

\begin{tabular}{|c|c|c|}
\hline Patent application no. & Title & Specification (ref) \\
\hline US20040167646A1 & $\begin{array}{l}\text { Methods for dental } \\
\text { restoration }\end{array}$ & $\begin{array}{l}\text { provides a method for preparing dental } \\
\text { restorations (Methods for dental restoration) }\end{array}$ \\
\hline US $8,759,391 \mathrm{~B} 2$ & $\begin{array}{l}\text { Topical anesthetic } \\
\text { for rapid local } \\
\text { Anesthesia }\end{array}$ & $\begin{array}{l}\text { a drug is applied topically to an area for injection } \\
\text { such that the dermatological procedure } \\
\text { (cosmetic injections) can be performed in fifteen } \\
\text { minutes (Topical Anesthetic For Rapid Local } \\
\text { Anesthesia, n.d) }\end{array}$ \\
\hline US $3,860,704$ & $\begin{array}{l}\text { Dressing for dry } \\
\text { tooth socket }\end{array}$ & $\begin{array}{l}\text { the invention comprises a composition for } \\
\text { relieving pain and promoting healing in the } \\
\text { treatment of dry socket, following tooth } \\
\text { extraction (Dressing for dry tooth socket, n.d) }\end{array}$ \\
\hline US 7,021,932 B2 & $\begin{array}{l}\text { Device for tooth } \\
\text { extraction }\end{array}$ & $\begin{array}{l}\text { a tooth extraction device with a clamp assembly } \\
\text { to clamp a tooth to be extracted, and a handle so } \\
\text { that clamp assembly can be placed in the mouth } \\
\text { of the patient (Tooth Extraction Device, n.d) }\end{array}$ \\
\hline US 5,244,390 & $\begin{array}{l}\text { Dental scaling } \\
\text { instrument }\end{array}$ & $\begin{array}{l}\text { for scaling artificial dental abutments made of } \\
\text { titanium and it is dilute alloys, which are softer } \\
\text { than natural dentition without scratching the }\end{array}$ \\
\hline
\end{tabular}




\begin{tabular}{|c|c|c|}
\hline & & abutment surface (Dental Scaling Instrument, n.d) \\
\hline US 5,401,504 & $\begin{array}{l}\text { Use of turmeric in } \\
\text { wound } \\
\text { healing }\end{array}$ & $\begin{array}{l}\text { method of promoting healing of a wound in a } \\
\text { patient, which comprises administration of } \\
\text { turmeric to the patient (Use of Turmeric In } \\
\text { Wound Healing, n.d) }\end{array}$ \\
\hline US 6,955,538 B1 & $\begin{array}{l}\text { Equipment for } \\
\text { deposition of } \\
\text { medicine in } \\
\text { the mouth }\end{array}$ & $\begin{array}{l}\text { the method is designed to place a slow-release } \\
\text { supply of a substance in the oral cavity with a } \\
\text { device designed to implement Equipment } \\
\text { concerning the depot of medicament in the } \\
\text { mouth, n.d.) }\end{array}$ \\
\hline US OO5266330A & $\begin{array}{l}\text { Method for } \\
\text { treating pressure } \\
\text { ulcers using } \\
\text { calendula }\end{array}$ & $\begin{array}{l}\text { method for treating human disease conditions and } \\
\text { use of the plant extract calendula to treat } \\
\text { ulcerative skin conditions (Method for treating } \\
\text { pressure ulcers using calendula, n.d) }\end{array}$ \\
\hline $\begin{array}{l}\text { Indian Patent } \\
\text { Application } \\
\text { Number } \\
\text { 1266/DELNP/2005 }\end{array}$ & $\begin{array}{l}\text { Dental care herbal } \\
\text { formulation and } \\
\text { it is preparation }\end{array}$ & $\begin{array}{l}\text { a herbal formulation comprising a combination of } \\
\text { active fractions from Citrullus colocynthis } \\
\text { and neem for control of dental plaque and } \\
\text { gingivitis (Dental Care Herbal Formulation and } \\
\text { Its Preparation Thereof, n.d) }\end{array}$ \\
\hline $\begin{array}{l}\text { Indian Patent } \\
\text { Application } \\
\text { Number } \\
\text { 2002/MUM/2011 }\end{array}$ & $\begin{array}{l}\text { Pharmaceutical } \\
\text { combination }\end{array}$ & $\begin{array}{l}\text { a combination containing Hydroxychloroquine } \\
\text { and a DPP-IV inhibitor or their pharmaceutically } \\
\text { acceptable salts for prevention, slowing the } \\
\text { progress, improvement, treating a condition or } \\
\text { a disease due to metabolic disorders } \\
\text { (Pharmaceutical Combination, n.d) }\end{array}$ \\
\hline $\begin{array}{l}\text { Indian Patent } \\
\text { Application } \\
\text { Number }\end{array}$ & $\begin{array}{l}\text { A device for } \\
\text { Securing a dental } \\
\text { implant in bone }\end{array}$ & $\begin{array}{l}\text { Device for securing a dental implant in bone } \\
\text { tissue, for example, the jawbone of a patient or } \\
\text { the zygomatic bone of a patient. The application } \\
\text { also relates to a method of making a surgical }\end{array}$ \\
\hline 4803/KOLNP/2008 & Tissue & $\begin{array}{l}\text { template and to a process of securing a dental } \\
\text { implant in bone tissue (Device for Securing A } \\
\text { Dental Implant In Bone Tissue, n.d) }\end{array}$ \\
\hline US 2008/0209650 A1 & Oral hygiene Device & $\begin{array}{l}\text { devices employ an ultrasound transducer (Oral } \\
\text { Hygiene Devices, n.d) }\end{array}$ \\
\hline
\end{tabular}

On the other hand, blanket prohibition has been laid by developing countries on medical procedures via statutory provisions. This dissimilarity between the developing and developed nations is raised due to social circumstances and national patent processes. (WMA Statement on Patenting Medical Procedures (MAY, 2019) In dentistry, various patents have been granted in foreign countries, which may be because of a better understanding of IPR. Patent grants and applications are very few in India. (Bijle, 2011) some of the patent applications are shown in table 2 .

Intellectual property is the creation of the human mind (intellect) (Bijle, 2011), and the right granted is termed an 'Intellectual Property Right' (IPR). (What is Intellectual property? 2020) A patent is granted for 20 years to an inventor, excluding others from using or making a particular invention. (Gupta et al., 2018) For that period, patent holders enjoy the benefits, and the public can not enjoy them freely (Gupta et al., 2018., Bronwyn, 2007).

Once the term of the granted patent is over, it can't be patented again, and the patent goes into the public domain, i.e., it becomes public property (Gupta et al., 2018), as shown in Figure 2. 


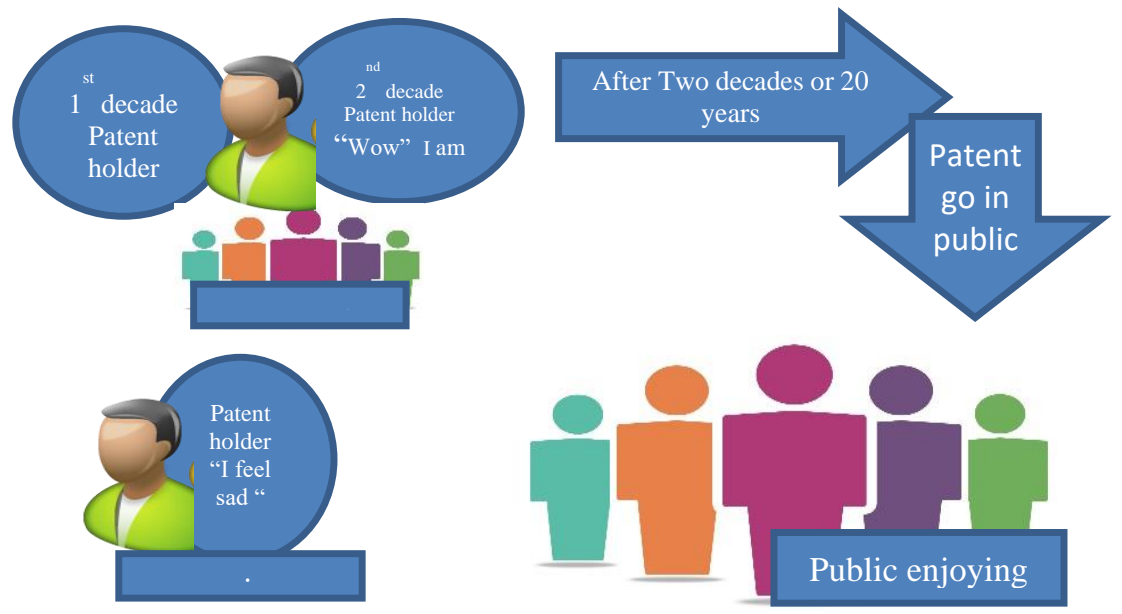

Figure 2. Term of Patent

Indian Patent Act, 1970 allows patentability of pharmaceuticals or medical devices such as scalpels, surgical sutures, staplers, stents, diagnostic kits, and reagents. (Indian patent act 1970, 2015) There has been so much research and development in medical science. However, medical methods are still nonpatentable in the Indian patent system with issues and reasons (Table no.3) (WMA Statement on Patenting Medical Procedures, 2019).

Table 3. Reasons on the grounds of which medical methods are not subject to patentability (WMA Statement on Patenting Medical Procedures, 2019)

\begin{tabular}{l} 
Reasons \\
\hline Ethics intrinsic in the medicine practice \\
Unbalancing of health care by economic benefit, raised financial load as \\
well as damage to privacy and confidentiality of patient \\
Access to that medical method will be decreased for the patient due to \\
provisions of the license \\
Physicians might prefer an inferior method instead of licensing the patented \\
method, thus compromising safety \\
The threat of infringement will prevent advanced medical methods be \\
adopted \\
Decreased peer review of the method with a resultant decline in safety and \\
quality of novel methods \\
In some countries use of a patented invention is not allowed for academic \\
and research purposes \\
The exploitation of privacy of the patient after examining the patient record \\
for evaluating if a physician has performed patented method
\end{tabular}

Today research and innovation is an observed phenomenon but not every research is patentable. In recent years there has been a remarkable increase in Patents in dentistry. Dental professionals are concerned with practical problems of patent processing to manufacture equipment used to diagnose, prevent, and treat disease. Inventions are there in dentistry, but knowledge about IPR and its substantial value in society are questionable. (Bijle, 2011). The present study was conducted among healthcare professionals of different streams, i.e., dental, medical, ayurvedic, and homeopathic, to assess knowledge and awareness of health care professionals about the Indian patent system and evaluate barriers in IPR i.e.,, Paten History of patents is too long. Patent granting was initiated in the 
fourteenth century. The first Indian Patent application was made in 1856 based on the British patent system, and it has provided a patent term of 14 years. Several acts and amendments followed it. ( Saha et al., 2011) shown in table 4. ( What is Intellectual property? 2020; Manual of patent practice and procedure the patent office, India, 2008; Ahmed \& Kumar 2017). It is briefed in table 1.

Table 4. History of Intellectual Property Right in India

\begin{tabular}{|c|c|c|c|}
\hline Year & Legislation & Salient features & Objective \\
\hline 1856 & Act VI of 1856 & first patent application in India was made & $\begin{array}{l}\text { to promote novel and useful invention } \\
\text { encouragement of disclosing their } \\
\text { inventions }\end{array}$ \\
\hline 1856 & Patents Act i.e., Act VI & $\begin{array}{l}\text { Indian Government promulgated legislation to } \\
\text { grant "exclusive privileges }\end{array}$ & $\begin{array}{l}\text { to encourage inventions of new } \\
\text { manufactures }\end{array}$ \\
\hline 1859 & Act XV of 1859 & $\begin{array}{l}\text { modification from grant of exclusive privileges } \\
\text { to useful inventions and priority period extended } \\
\text { from six to twelve months. }\end{array}$ & $\begin{array}{l}\text { Protection of only inventions and not } \\
\text { meant for designs. }\end{array}$ \\
\hline 1872 & $\begin{array}{c}\text { Patterns and Designs } \\
\text { Protection Act' (Act XIII) of } \\
1872\end{array}$ & $\begin{array}{l}\text { to include novel \& unique pattern or design or } \\
\text { the application of such pattern to an article of } \\
\text { manufacture under 'new manufacture.' }\end{array}$ & $\begin{array}{l}\text { to amend } 1859 \text { act } \\
\text { to protect designs }\end{array}$ \\
\hline 1883 & Act (XVI of 1883) & provision for novelty of the invention & to amend the 1972 act \\
\hline 1911 & $\begin{array}{l}\text { (Act II of 1911) } \\
\text { Indian Patents and Designs } \\
\text { Act }\end{array}$ & $\begin{array}{l}\text { patent administration brought under the } \\
\text { management of Controller of Patents }\end{array}$ & $\begin{array}{l}\text { Replacing all previous legislation on } \\
\text { patents and designs. }\end{array}$ \\
\hline 1920 & amendment & $\begin{array}{l}\text { reciprocal arrangements with the UK and other } \\
\text { countries for securing priority. }\end{array}$ & to amend 1911 act \\
\hline 1930 & amendment & $\begin{array}{l}\text { grant of secret patents, use of an invention by } \\
\text { Government, powers of the Controller to rectify } \\
\text { patent register and term of the patent increased } \\
\text { from } 14 \text { years to } 16 \text { years of addition }\end{array}$ & \\
\hline 1945 & amendment & $\begin{array}{l}\text { filing provisional specification and submission } \\
\text { of complete specification within a period of } 9 \\
\text { months }\end{array}$ & to amend 1911 act \\
\hline 1949 & By Government of India & $\begin{array}{l}\text { under the Chairmanship of Justice (Dr.) Bakshi } \\
\text { Tek Chand, a committee was constituted }\end{array}$ & $\begin{array}{l}\text { to ensure that the patent system is } \\
\text { conducive to the national interest. } \\
\text { prevention of misuse or abuse of } \\
\text { patent right in India }\end{array}$ \\
\hline 1950 & (Act XXXII of 1950) & $\begin{array}{l}\text { Ensure the working of inventions and } \\
\text { compulsory license/revocation. }\end{array}$ & to amend 1911 act \\
\hline 1952 & Act LXX of 1952 & $\begin{array}{l}\text { compulsory license in } \\
\text { for the patent in case of food, medicines, } \\
\text { insecticide, germicide or fungicide or an } \\
\text { invention for surgical or curative devices }\end{array}$ & The next step to amend the 1911 act \\
\hline 1957 & By the Government of India & $\begin{array}{l}\text { Justice N. Rajagopala Ayyangar Committee was } \\
\text { appointed }\end{array}$ & $\begin{array}{l}\text { To amend the } 1911 \text { act, which was not } \\
\text { fulfilling its objective. } \\
\text { To examine the question of revision of } \\
\text { the Patent Law and advise the } \\
\text { government accordingly. }\end{array}$ \\
\hline $\begin{array}{l}1965- \\
1967\end{array}$ & Patents Bill, 1965 & $\begin{array}{l}\text { an amended bill referred to a Joint } \\
\text { Parliamentary Committee was introduced }\end{array}$ & $\begin{array}{l}\text { significant changes in the patent law } \\
\text { to purpose patent act } 1970\end{array}$ \\
\hline $1970-$ & the Patents Act, 1970 & on 20th April, most provisions of the 1970 Act & Based on the result of the final \\
\hline
\end{tabular}




\begin{tabular}{ccl}
\hline 1972 & were active \\
\hline 1999 & the Patents & $\begin{array}{l}\text { The amended Act that was brought into force } \\
\text { from 1st January 1995 }\end{array}$ \\
(Amendment) Act, 1999 &
\end{tabular}

recommendation of the Committee

replaced 1911 act

To amend the patent act 1970, provided applications for product patents in drugs, pharmaceuticals, and agrochemicals.

Allowed Exclusive Marketing Rights (EMR) to sell these products in India, subject to fulfillment of certain conditions, etc

\begin{tabular}{|c|c|c|}
\hline $\begin{array}{l}2002- \\
2003\end{array}$ & $\begin{array}{l}\text { the Patents } \\
\text { (Amendment) Act, } 2002 \text { (Act } \\
38 \text { 0f 2002). }\end{array}$ & $\begin{array}{l}\text { replaced the earlier Patents Rules, } 1972 \\
\text { introduction of the new Patent Rules, } 2003 .\end{array}$ \\
\hline $\begin{array}{l}2004- \\
2005\end{array}$ & $\begin{array}{l}\text { Patents (Amendment) } \\
\text { Ordinance, } 2004 \text { later } \\
\text { replaced by the Patents } \\
\text { (Amendment) Act } 2005 \text { (Act } \\
15 \text { Of } 2005 \text { ) }\end{array}$ & active from 1st January 2005. \\
\hline $\begin{array}{l}2005- \\
2006\end{array}$ & $\begin{array}{l}\text { the Patents (Amendment) } \\
\text { Rules, } 2005 \text { and the Patents } \\
\text { (Amendment) Rules, } 2006\end{array}$ & $\begin{array}{l}\text { last amendments made effective from 5th May } \\
2006\end{array}$ \\
\hline
\end{tabular}

the second amendment to the 1970 Act

20 years term of the patent for all technology. Mandatory publication of applications after 18 months from the date of Filing etc

the third amendment to the Patents Act 1970, deletion of the provisions relating to Exclusive Marketing Rights (EMRs).

Extension of product patents to food, drugs, chemicals, and microorganisms. Grant of a compulsory license for the export of medicines to countries with limited capacity to meet emergency public health circumstances.

\subsection{Gaps of the study}

Research studies from the past evaluated IPR among other professionals except for medical professionals. In literature, no study has been found related to this topic. There is a wide gap in the survey of the need for patent education. Only a few studies in India have focused on other IPRs, not on the patents like in our research.

\subsection{Rationale of the study}

Mere evaluation of knowledge does not provide information. There is a stringent need to assess the barriers among Indian professionals and pitfalls in the education system.

\subsection{Significant contribution and the novelty from this present study}

Present study will contribute to new gaps in patent education since this type of study was not conducted among medical professionals before. It will encourage other authors to conduct more research on this topic and strengthen patent education.

\section{Method}

This cross-sectional study was conducted from a period of May 2017 to January 2018. A convenience sampling method was used. A well-designed study questionnaire (offline) was used, which was divided in 7 parts. The first part consisted of 3 questions (1-3) ; demographic information, Part two consisted of 3 questions containing basic knowledge about Patent, part 3 consisted of 2 questions (4-5) regarding attitude towards patent, part 4 consisted of 2 questions (6-8); regarding knowledge about the patent procedure and grant, part 5 consisted of question (9)about knowledge of patentability of treatment methods part 6 consisted of 2 questions (10-11); for barriers in the patent knowledge, part 7 consisted of 2 questions (1213); for participant's enthusiasm towards the patent. Participation in the research was voluntary. Only those participants who were interested and willing to participants enrolled in the study. The confidentiality of research participants was kept throughout the study. 175 private practitioners and academicians were approached from different streams i.e. (dental, medical, ayurvedic, and homeopathic). Out of these, 22 participants refused to participate in the study, and 15 questionnaires were found incomplete, so we excluded them from the final analysis, so we had 138 
questionnaires for final analysis. Data was fed in an excel sheet and analyzed for percentage, correct responses, mean, p-values, and ANOVA followed by a post hoc test using SPSS version 20, IBM SPSS Statistics for Windows, Version 20.0. IBM Corp., Armonk, NY, USA.
The present study was conducted to gather knowledge for innovation and patent education among professionals from different streams. The response rate in the present study was good i.e. 138/175 (78.8\%).

\section{Findings}

Table 5. Gender Wise Distribution Study Participants

\begin{tabular}{|c|c|c|}
\hline Gender & Number & Percentage \\
\hline Male & 71 & $51.4 \%$ \\
\hline Female & 67 & $48.5 \%$ \\
\hline
\end{tabular}

Gender-wise distribution comprised of 71/138 $(51.4 \%)$ male participants and 67/138 (48.5\%) female participants shown in table no.2. Out of 138 participants, medical professionals were 56/138
$(40.5 \%)$, dentists were 25/138 (18.1\%), 29/138 (21.0\%) participants were from ayurvedic practice, and $28 / 138(20.2 \%)$ participants were from homeopathic.

Table 6. Age and Profession Wise Distribution of Study Participants

\begin{tabular}{ccc}
\hline Age & Number & Percentage \\
\hline $22-30$ & 15 & $11.0 \%$ \\
$30-40$ & 34 & $25.0 \%$ \\
$40-50$ & 26 & $19.0 \%$ \\
$50-60$ & 42 & $30.0 \%$ \\
60 \& above & 21 & $15.0 \%$ \\
\hline Profession & Number & Percentage \\
\hline Medical & 56 & $40.5 \%$ \\
Dental & 25 & $18.1 \%$ \\
Ayurvedic & 29 & $21.0 \%$ \\
Homeopathic & 28 & $20.2 \%$ \\
\hline
\end{tabular}

In our study, 15 participants were in the age group of 22-30 yrs, 34 participants were in the age group of $30-40 \mathrm{yrs}, 26$ participants were in the age group of 40 $50 \mathrm{yrs}, 42$ participants were in the age group of 50-60 yrs, 21 participants were in the age group of 60 and above. Professions distribution include 56, 25, 29, and 28 professionals from medical, dental, ayurvedic, and homeopathic.

\subsection{Basic knowledge of Indian professionals about the patent system}

Our study indicated a poor basic knowledge about the Indian patent system, and there was no statistically significant difference in the understanding among various groups. The patent is an intellectual property right, and it is a technical document that requires inputs from technical and legal experts for protection. (Gupta et al., 2018) In our study, 94\% of participants had less than $50 \%$ knowledge, and $6 \%$ had more than $50 \%$ knowledge about this statement.

\subsection{The attitude of Indian professionals towards patent}

In our study, none of the participants had any previous experience with the patent application. On further exploration, it was found that they did not file a patent for an invention before because 99/138 (72\%) did not have time, 10/138 (7\%) were not interested in a patent application, and 29/138 (21\%) possessed a 
lack of awareness regarding this topic but were interested in applying.

\subsection{Knowledge of Indian professionals about patent protection and grant procedure}

Patent protection can be applied for products as well as processes. (Gupta et al., 2018) In our study, only $3 \%$ of participants correctly responded to this statement. The patent is a right granted by the government to an inventor excluding others from making, using, or selling a particular invention. (Gupta et al., 2018) Our 93\% of participants responded correctly, and 7\% did not know. A patent is a territorial right i.e. patent granted once in a country is valid only in the country where the application has been applied, and it is not a worldwide grant. (Gupta et al., 2018) In our study, $74 \%$ of participants did not know about this statement, and $26 \%$ responded incorrectly.

\subsection{Knowledge of Indian professionals about the term of the patent for an invention}

Once granted a patent for an invention it is term is 20 years after applying to the patent office (Gupta et al., 2018), so an investor can enjoy their right for 20 years. A patent allows an inventor to disclose an invention publically rather than secrecy. (Gupta et al.,2018) None of the participants were aware of the statement. Once the term of the granted patent is over, it cannot be patented again, and the patent goes in the public domain i.e. it becomes public property. (Gupta et al., 2018) A large majority i.e. 96\% participants, did not respond, and a very few i.e. only $4 \%$, responded incorrectly that it can be patented again.

\subsection{Knowledge of Indian professionals about patentability of medical and dental treatment methods}

Medical and dental treatment or surgical procedures are not patentable in India. (WMA Statement On Patenting Medical Procedures, 2019; Gupta et al.,2018) In our study $2 \%$ participants responded that these methods are not patentable while $34 \%$ participants were having misconception that these methods are patentable and $64 \%$ did not give any response i.e. did not attempt question.

\subsection{Barriers in the knowledge of patent among Indian professionals}

Participants accepted that they were not acquainted with patent knowledge. Since they were never taught patent in their educational curriculum. Lack of topic in educational curriculum was found a barrier in patent knowledge. All participants responded that this topic was never discussed in continuing education programs, seminars, conferences attended by them.

\subsection{Enthusiasm towards patent among Indian professionals}

In our study, $99 \%$ of the study population did not explore the patent search engine, a structure-based search in the patent database. (Gupta et al., 2018) Due to lack of time, inadequate knowledge, and lack of interest. Only $1 \%$ of study participants showed interest in exploring and increase their knowledge.

As the knowledge was found very poor concerning the Indian patent system among participants, analysis of our study data was not presentable through mean, p-values, and ANOVA followed by a post hoc test, so results were presented only in percentage form.

\section{Discussion}

Our study was conducted to evaluate Indian professionals' knowledge for innovation and the need for patent education. Education of patent is an important aspect of faculty development programs. The findings from our study indicated a poor show of patent education. Traditional medicine serves as an important element of human health care with added commercial value. Researchers or companies may also claim IPR over biological resources and traditional knowledge after making slight modifications in the existing invention. The patent applications in the case of traditional medicine, natural products, and herbal medicinal products possess their IPR policies showing a rapid growth in herbal medicine. (Saha, 2011) In our study, only $3 \%$ of participants responded about the need for patent protection, in contrast to Ahmed et al., where $57 \%$ of respondents were aware of the need to protect IPR. (Ahmed \& Kumar, 2017) )This indicates a lack of knowledge. In our study, $94 \%$ of participants had less than $50 \%$ knowledge, and $6 \%$ had more than $50 \%$ knowledge.

Further, in one study carried in Lucknow, $50 \%$ of research scholars were aware of patent. (Ahmed \& Kumar, 2017) In our study, results showed a lack of experience in patent application. Large numbers of respondents were not aware of the laws relating to patent protection in contrast to the findings of a study carried by ahmed et al. where $50 \%$ of respondents were aware of IPR protection laws. (Ahmed \& Kumar, 2017) Researchers in the academic field are deficient in awareness of IP-related issues to proceed with patent application procedures for their invention and publication. Once the public disclosure of research findings happens, the invention is not considered to novel anymore. (Intellectual property and access to medicines, 2012).

Universities and academic hospitals generate revenue from clinical care and teaching costs to capture business operations and cost of employees, 
leaving minimum residual finances for further development of product and clinical trials. On patent expiry, generic pharmaceutical companies replicate drugs spending only a part of the original costs of drug development, reducing the original cost of the drug (Taylor D, 2015). They have to verify only bioequivalence and the quality of the drug in terms of pharmaceuticals. Literature review suggests that barriers among health care inventors are limited knowledge of complicated international patent laws with inadequate access to qualified IP lawyers. In addition, increased price (price of filing, legal counseling, and maintenance of patent) increases the product price, time, and logistics resisting them from patent procedure. (Chao \& Mody, 2015). In our study, all participants accepted that they were not acquainted with patent law. They have never been taught about patent in their curriculum, and the topic was never discussed in workshops, continuing education programs, seminars, conferences. This lack of topic in the curriculum was found a major barrier, Whereas in one study among library professionals in domains of medical sciences, the source of awareness were found books, the internet, friends, formal courses. (Gnanasekaran D, 2014) In our study, 93\% of participants responded that patent is a right in contrast to the findings $(60 \%)$ of the study carried by Ahmed et al. (Ahmed \& Kumar, 2017). Curricular adequacy among professionals is also found to be deficient (Gupta, 2019). motivation level was also found inadequate. (Bansal \& Meenakshi, 2016). Our study found no significant difference in knowledge among participants, but it does not mean there is no difference clinically. (Prasad, 2019).

A large majority (99\%) did not explore patent databases due to a lack of time and knowledge. In one study, $23.6 \%$ of participants visited sites to be informed about technological innovations. (Metallidou, 2020) Research advances in science and medicine provide the latest interpretations of already existing facts. Research is the activity of human origin that utilizes intellect to investigate and interpret. There arises a need for greater participation in research by the physicians as well as clinicians and patients. (Gupta et al., 2019) Since intellectual property (IP) is an original creation of the human mind. In our study, only $1 \%$ of the participant showed interest in exploring and increasing their knowledge as a part of the research. In a study carried out by Ahmed et al in Lucknow, only $40 \%$ of the respondents were aware of the contribution of IPR in research and innovation.(Ahmed \& Kumar, 2017) None of the participants had any previous patent application experience indicating weak research activity among participants, lack of interest. They did not file a patent for an invention. This is again because of lack of time, awareness, and absence of interest in the research area. In a study carried in Greece, only $18.3 \%$ of participants had consideration for an innovation. (Metallidou, 2020) This study will contribute to filling existing gaps in the field of IPR among Indian professionals. Findings from this study will reveal new gaps in the literature that had not been previously exposed or adequately described by others. Our study necessitates strengthening patent education with a weak backbone.

\section{Conclusions}

The findings of the study revealed poor knowledge of patents due to the flawed system in our country. Developing countries like India are in extreme demand for improvement or amendments in existing patent law. In addition to improvements in the Indian patent system, there is a stringent need to promote progress and development of medical sciences in India. Research and innovation is an important criterion for application and approval of such activities.

The major implication of our study was the weakened backbone of Indian patent education among medical professionals. Patent education is not given due importance among them. In past, no such research has been carried out among medical professionals, but some studies among engineering and pharmacy professionals have been conducted. Medical sciences pay consideration to this topic only for smoothening of accreditation procedure, not for educational and professional upliftment. Medical education emphasizes only research but not on IPR, which is the next step to research. We conclude that there is a great need for patent education for professional and institutional growth. Dental, Medical, and other associations should include IPR in their workshops, conferences as a significant part of the continued education program. Accreditation bodies necessitate educational institutions to have completed research projects and filed patent applications. There arises a stringent need for medical bodies to encourage affiliated institutions, universities to teach IPR.

\section{References}

Brajnovic, I. (2013). U.S. Patent No. 8,540,510. Washington, DC: U.S. Patent and Trademark Office.

Ahmed, S., Kumar, V.P. (2017). Awareness regarding intellectual property rights a survey amongst the P.G. and Ph.D. students of Babasaheb Bhimrao Ambedkar University, Lucknow International Journal of Law, 3(4):184-190. 
http://www.lawjournals.org/download/173/3-443-906.pdf.

Bansal, R,N., Meenakshi, M. (2016). A Case Study of Motivational Levels among Personnel Working in a Government Teaching Hospital of Punjab. Biomed Pharmacol J, 9(2), 585-591 DOI: http://dx.doi.org/10.13005/bpj/976.

Bijle, M. N. A. (2011). Patent law in dentistry: An overview. Indian Journal of Dental Research, 22(4), $574 . \quad$ DOI: http://www.ijdr.in/text.asp?2011/22/4/574/90301

Bronwyn, H, Hall. (2007). Contribution to The New Palgrave: A Dictionary of Economics, Page:118. $\quad\left(2^{\text {nd }} \quad\right.$ edition $)$. https://eml.berkeley.edu/ bhhall/papers/BHH06_ Patents_Palgrave.pdf.

Chao, T. E., \& Mody, G. N. (2015). The impact of intellectual property regulation on global medical technology innovation. BMJ Innovations, 1(2). 49-50. DOI:10.1136/bmjinnov-2014-000033.

Dixit, T., Srivastava, S., Sahu, S., Selvamurthy, W. (2018). Intellectual property evolution and innovation ecosystem as effective tools in strengthening Indian healthcare sector. Current Science, DOI:10.18520/cs/v114/i08/1639-1649

Gnanasekaran, D., Balamurugan, S. 2014. Intellectual Property Rights Awareness by Stakeholders: An Empirical Study. European Academic Research. 2(8) 10487-10505.

Gupta, S., Bansal, R. N., Sodhi, S.P.S., Brar, G.K., Bansal, R. (2018). Patent: A Journey from Idea To Patent. Innoriginal International Journal of Sciences.

$5(6): 5-11$. https://www.innoriginal.com/index.php/iijs/articl e/view/209

Gupta, S., Bansal, R.N. (2019). Curricular adequacy on basics of Clinical Trials among young doctors. Indian Journal of Pharmacology, 51(2);109-15. DOI: 10.4103/ijp.IJP_184_18.

Gupta, S., Bansal, R.N., Bansal, R., Sodhi, S.PS., Brar, G,K. (2019).Physician's Participation in Clinical Research -a questionnaire study. Journal of Pre-Clinical and Clinical Research, 13(2):57-60. DOI: 10.26444/jpccr/108899.

Heus, J.J., Pauw, E., Leloux, M. et al. (2017). Importance of intellectual property generated by biomedical research at universities and academic hospitals. Journal of Clinical and Translational Research, 3(2): 250-259. DOI: 10.18053/jctres.03.201702.005.
Indian patent act $1970 . \quad$ (2015). http://www.ipindia.nic.in/writereaddata/Portal/IP OAct/1_31_1_patent-act-197011march2015.pdf.

Intellectual property and access to medicines. (2012). (n.d)

http://apps.who.int/medicinedocs/documents/s19 580en/s19580en.pdf

Kassiri,M.A., Corejova T. (2015).Importance of Patent and innovation in educational institutions. CBU international conference on innovation, technology transfer and education. Prague,Czech Republic. 271-

275.doi:http://dx.doi.org/10.12955/cbup.v3.611.

Metallidou, C.K., Psannis, K.E., Alexandropoulouegyptiadou. E., Metallidou, C, K et al. (2020). Survey on the Patent Law Awareness and the Entrepreneurial Trend of Greece's Graduates of Technology Institutes. IEEE Access 8:1-1. DOI:10.1109/ACCESS.2020.2994099

Method for treating pressure ulcers using calenoula. (n.d.).

https://patentimages.storage.googleapis.com/76/7 8/8c/4d1bd2107b03ac/US5266330.pdf.

Method of Treatment. A Patent Perspective. (2017) Patent wire Consultants Pvt. Ltd. www.patentwire.co.in.

Methods for dental restoration (n.d)https://patents.google.com/patent/US200401 67646

Oral Hygiene Devices. (n.d.). https://patentimages.storage.googleapis.com/83/a 8/23/7774a8192f008b/US20080209650A1.pdf.

Pharmaceutical Combination (n.d.). http://www.allindianpatents.com/patents/280009pharmaceutical-combination.

Prasad, K. (2019). Statistical. Significance versus Clinical Importance. Neurol India, 67 : 1513-4. DOI: $10.4103 / 0028-3886.273608$

Saha, C,N., \& Bhattacharya, S. (2011). Intellectual property rights: An overview and implications in pharmaceutical industry. J Adv Pharm Technol Res, 2(2): 88-93. doi: 10.4103/2231-4040.82952.

Taylor, D. (2015). The Pharmaceutical Industry and the Future of Drug Development. Pharmaceuticals in the Environment, 1-33 DOI: 10.1039/9781782622345-00001.

Tooth Extraction Device. (n.d.). https://patentimages.storage.googleapis.com/7a/5 c/f6/18bb60eda5ad98/US7021932.pdf. 
Topical Anesthetic For Rapid Local Anesthesia. (n.d.).

https://patentimages.storage.googleapis.com/0b/5 9/26/5465f3234cd027/US8759391.pdf.

Use of Turmeric In Wound Healing. (n.d.). https://patentimages.storage.googleapis.com/c5/4 a/0f/bd0d3ab5478eaa/US5401504.pdf.

What is Intellectual property? (2020). (n.d) https://www.wipo.int/edocs/pubdocs/en/wipo_pu b_450_2020.pdf

WMA Statement on Patenting Medical Procedures (MAY, 2019) https://www.wma.net/policiespost/wma-statement-on-patenting-medical procedure 